\title{
DEVELOPMENT OF SUSCEPTIBILITY OF THE COTTON LEAF WORM, SPODOPTERA LITTORALIS TO NOMOLT COMPOUND IN RELATION TO SOME BIOLOGICAL AND BIOCHEMICAL CHANGES IN THE INSECT BODY
}

\author{
IBRAHIM, ELSHAIMAA N. ${ }^{1}$, AZZA K. EMAM ${ }^{2}$, \\ K. WESHAHY ${ }^{2}$ and AZIZA E. ABDEL-AAL ${ }^{1}$
}

1. Plant Protection Research Institute, ARC, Dokki, Giza, Egypt.

2. Plant Protection Dept., Fac. Of Agric., Ain Shams Univ., Shoubra El-Kheima, Cairo, Egypt.

(Manuscript received 7 May 2015)

\begin{abstract}
$\mathrm{T}$ he susceptibility of the $4^{\text {th }}$ instar larvae of the Egyptian cotton leafworm, Spodoptera littoralis (Boisd.) to the chitin synthesis inhibitors, nomolt was evaluated in the laboratory for 10 generations. The fourth instar larvae were treated with various concentrations of nomolt insecticide for $48 \mathrm{hrs}$ in each generation until $\mathrm{F} 10$ and $\mathrm{LC}_{50} \mathrm{~S}$ were calculated after 7 days post treatment in each generation. The obtained results showed that the resistance ratios of the selected generations were increased to $1.2709,1.2894,2.3034$ and 3.0117 folds, the F3, F6, F8 and F10 generations, respectively. Based on the biological aspect, larval durations were increased significantly in the selected generations compared to the control. Furthermore, percentage of pupation was reduced in all the treated generations, which being 56.7, 55.0, $43.85,27.35,24.66$ and $33.56 \%$ the adult emergence was significantly affected as it was $82.09,70.33,37.71,55.06,41.18$ and $43.65 \%$ in treated F0, F1, F3, F6, F8 and F10 of the selected generations, respectively. The activities of the measured enzymes at 6 days after treatment of the fourth instar larvae showed up and down pattern through the selected ten generations. The activity of $a$ and $\beta$ esterases as well as protease enzymes was back to normal activity as that of control in the tenth generation meanwhile chitinase enzyme activity remained significantly higher than that of the control.

Key words: IGR's - Teflubenzuron- Spodoptera littoralis- $\mathrm{a}$ and $\beta$ esterases- Protease - chitinase.
\end{abstract}

\section{INTRODUCTION}

The Egyptian cotton leaf worm, Spodoptera littoralis (Bosid.) is one of the most important pests in Egypt and other countries in Africa and Asia. It attacks several host plants specially the cotton crop which is considered one of the main sources of the economy in Egypt.

Insect growth regulators (IGR's) received great attention as a hope for the future of insect control. Among these insecticides, chitin synthesis inhibitors (CSI's) was Nomolt which interferes with the chitin deposition. Occurrence of chitin is mainly 
restricted to arthropods, fungi and nematodes, and does not occur in vertebrates. These compounds cause a qualitative selectivity to both other phyla of invertebrates and vertebrates. Ingestion of chitin synthesis inhibitors by insect larvae disturbed endocuticular deposition during molting process because it blocks chitin synthesis. The blocking of chitin synthesis occurs by disruption the function of connecting $\mathrm{N}$ acetylglucose amine moieties to chitin chain.

The resistance problem is the greatest single challenge facing applied entomologists today, because of the widening circle of cross and multiple resistance among the insect pests, the diminishing number of effective commercial insecticides and the exponentially- increasing costs of development of new insecticides. In 1938, there were already 7 species showed resistance to insecticides toxicity and in 1988 there were closed to 500 resistant species. More significantly, insects with multiple resistances are becoming increasingly common. This often occurs when different groups of insecticides interfere with a common target that has changed (Brattsten, 1989).

In this study, the development of resistance in the cotton leaf worm Spodoptera littoralis after treating the fourth instar larvae with nomolt compound for ten generations was determined, in addition, the changes in some biological and biochemical aspects in the larval homogenate at six days after treatment was measured.

\section{MATERIALS AND METHODS}

\section{Rearing Technique}

The colony of the cotton leaf worm Spodoptera littoralis (Bosid.) was obtained from the division of the Cotton Leaf Worm, Plant Protection Research Institute, Agricultural Research Center larvae were reared for about 13 generations on castor been leaves (Ricinus communis $\mathrm{L}$ ) before any treatment as the method described by El- Defrawi et al. (1964).

\section{Insecticide Used:-}

Common Name: Chitin synthesis inhibitors. (nomolt, EC $15 \%$ ) from Treade Name : Nomolt 15\% EC provided from BASF Agri production.

\section{Structural formula:}

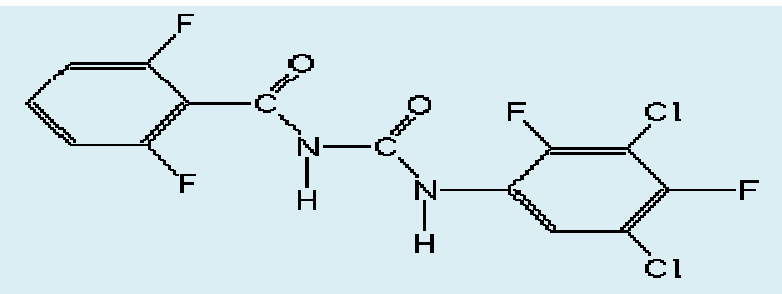




\section{Toxicological studies:}

Dipping method was used in this bioassay. Fourth instar larvae were fed on treated castor bean leaves in different concentrations of the tested compounds for 3 seconds. One hundred larvae were divided into four replicates, each 25 larvae were used four concentration (2.0, 1.0, 0.5 and $0.25 \mathrm{ppm}$ ) were used in this study. A control experiment was performed using castor been leaves dipped in water. The tested larvae were fed on treated leaves for 48 hrs. then the survived larvae were transferred to other clean jars and supplied daily fresh castor bean leaves for 7 days after treatment. The mortality percentage was recorded daily and corrected according to Abbott's formula (Abbott, 1925). The LC -p lines software program was used to obtain the toxicity regression lines. Percentages of corrected mortalities were statistically analyzed according to Finney (1971) and the LC 50 value was determined.

Selection of resistance was carried out by rearing the larvae firstly on castor been leaves treated with $\mathrm{LC}_{50}$ value of nomolt. According to the response of treated insect to selection, a higher concentrations of the tested compound was sometimes used in subsequent generations.

In comparisons of the resist abilities as called resistance ratio ( $\mathrm{LC}_{50}$ of resistance strain / $\mathrm{LC}_{50}$ of control), differences of five folds or more (true resistance differences) were considered as indicating positive correlation, those between 1 and 4 folds ( tolerance differences) as indicated by Litchfield and Wilcoxon (1949).

\section{Biological Studies.}

Newly molted $4^{\text {th }}$ instar larvae treated with $\mathrm{LC}_{50}$ value of selected generation were examined daily to determine the larval and pupal durations as well as percentage of both pupation and adult emergence.

\section{Biochemical studies:}

\subsection{Preparation of samples for biochemical studies:}

Larvae were collected after six days following the treatment of the fourth instar, placed in ice containers and homogenized in appropriate buffer using a Teflon homogenizer surrounded with a jacket of crushed ice for 3 minutes. Homogenates were centrifuged at $8000 \mathrm{rpm}$ for 10 minutes at $4^{\circ} \mathrm{C}$ (Biofuge 28RS Heraeus, Sepatech centrifuge). The resulted supernatants were used directly for determination of enzymatic activity.

\subsection{Determenation of the enzyme activities:}

The activity of both $a$ and $\beta$ non-specific esterases, protease and chitinase were determined according to the method of Van Asperen (1962), Ishaaya et al. (1971) and Ishaaya and Casida (1974), respectively. 


\section{Statistical analysis procedure:}

The significance of the main effects was determined by using analysis of variance (ANOVA). The significance of various treatments was evaluated by Duncan's multiple range tests $(p<0.05)$. All analysis was preceded using a software package "Costat", a product of cohort software Ine. Berkley, California. (Duncan, 1955).

\section{RESULTS AND DISCUSSION}

\section{I-Toxicological studies}

The $\mathrm{LC}_{50}$ values of nomolt treatment against the fourth instar larvae through the selected generations were determined as $0.1809,0.2275,0.2308,0.4123$ and $0.5391 \mathrm{ppm}$, in F1, F3, F6, F8 and F10, respectively. The estimated resistance ratios were 1.0106 folds in F1 generation, then gradually increased in the following selected generations to reach $1.2709,1.2894,2.3034$, and 3.0117 folds in F3, F6, F8 and F10 generations, respectively compared to the treated parent (F0) [Table 1 and Fig. 1].

Ghoneim et al. (2012) studied the toxicity of thirteen insecticides of different classes under laboratory conditions against egg mass and $4^{\text {th }}$ instare larvae of of Spodoptera littoralis (Boisd.) field strain obtained from Gharbia Governorate in Egypt during 2010 season. The field population showed high resistance to pyrethroids and moderate resistance to both organophosphorus and carbamates, however it had low resistance to the chitin synthesis inhibitors used against the $4^{\text {th }}$ instar larvae.

Table 1 . Susceptibility of the $4^{\text {th }}$ instar larvae of $S$. littoralis (Boisd.) toxicity.

\begin{tabular}{|c|c|c|c|c|c|c|}
\hline \multirow{2}{*}{ Concentrations (ppm) } & \multicolumn{5}{|c|}{$\%$ Corrected Mortality } \\
\cline { 2 - 7 } & $\begin{array}{c}\text { Parents } \\
\text { (F0) }\end{array}$ & F1 & F3 & F6 & F8 & F10 \\
\hline 0.125 & 43.3 & 40.1 & 36.05 & 37.29 & 25.14 & 15.76 \\
\hline 0.25 & 60.0 & 58.5 & 56.15 & 55.48 & 40.35 & 29.87 \\
\hline 0.5 & 83.3 & 79.7 & 75.44 & 72.65 & 58.43 & 47.94 \\
\hline 1.0 & 93 & 91.4 & 89.11 & 85.94 & 75.34 & 66.44 \\
\hline 2.0 & 99 & 99 & 96.26 & 94.02 & 87.81 & 81.61 \\
\hline LC 50 - value & 0.179 & 0.1809 & 0.2275 & 0.2308 & 0.4123 & 0.5391 \\
\hline Resistance Ratio & & 1.0106 & 1.2709 & 1.2894 & 2.3034 & 3.0117 \\
\hline Slope function & $\begin{array}{c}1.6513 \pm \\
0.3102\end{array}$ & $\begin{array}{c}1.9282 \pm \\
0.1888\end{array}$ & $\begin{array}{c}1.8534 \pm \\
0.3172\end{array}$ & $\begin{array}{c}1.621 \pm 0.2 \\
965\end{array}$ & $\begin{array}{c}1.6385 \pm 0 . \\
2806\end{array}$ & $\begin{array}{c}1.5825 \pm 0 \\
.1516\end{array}$ \\
\hline 95\% Confidence limits & $\begin{array}{c}0.1034- \\
0.2568\end{array}$ & $\begin{array}{c}0.1446- \\
0.2164\end{array}$ & $\begin{array}{c}0.1498- \\
0.3062\end{array}$ & $\begin{array}{c}0.1416- \\
0.3204\end{array}$ & $\begin{array}{c}0.2915- \\
0.5641\end{array}$ & $\begin{array}{c}0.3114- \\
0.9713\end{array}$ \\
\hline
\end{tabular}




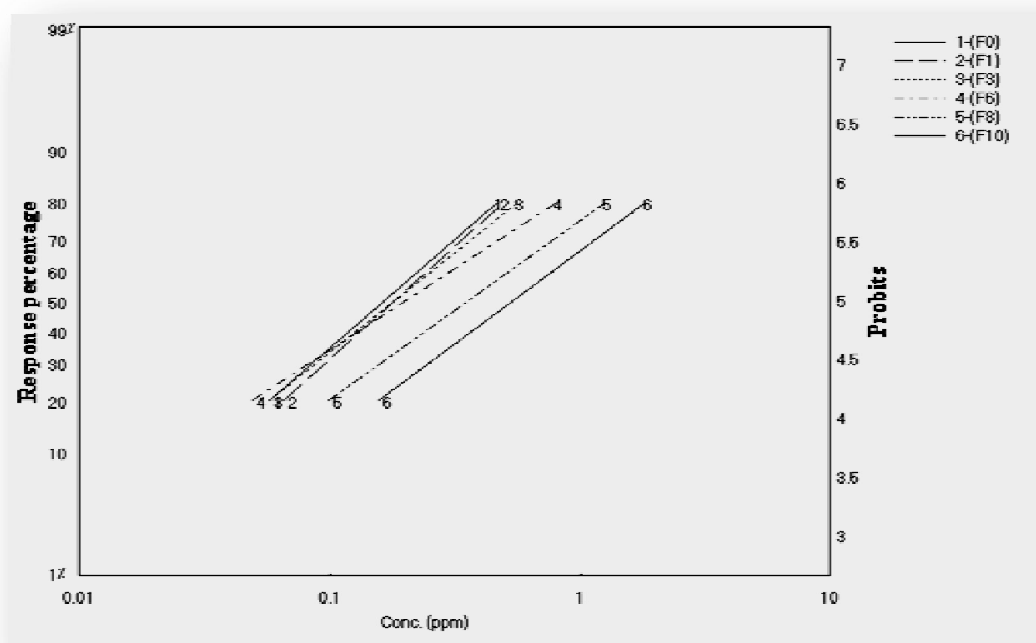

Fig. 1. Toxicity regression lines of the $4^{\text {th }}$ instar larvae of Spodoptera littoralis treated with nomolt insecticide during selected generations.

\section{Biological Studies.}

Effects of the devoloped resistance to nomolt toxicity on some biological aspects associated to the following selected generations of $S$. littoralis treated as $4^{\text {th }}$ instar larvae were recorded in Table 2.

Data indicated that larval duration increased significantly during the following selected generations, percentage of the increase in larval duration was12.5 in the treated parent (F0), 20.1, 17.5, 35.5, 45.0 and 20.8 in survived larvae obtained in F1, F3, F6, F8 and $\mathrm{F} 10$ generations, respectively.

The percentage of increase in the duration of pupal stage than those of the control was 3.81, 19.05, 9.52, 4.76 and 20.95 days in F0, F1, F3, F6 and F10 generations respectively. On the other hand, $\mathrm{F} 8$ had the same duration as in the control.

In addition, treatment of selected larvae with nomolt insecticide caused a reduction in pupation percentage compared with control in all respective treated generations which being $42.3,43.3,54.8,71.8,74.6$ and 65.4 .

The highest adult emergence percentage resulted from selected larvae with nomolt toxicity was achieved $82.09 \%$ in the parent generation (F0), while the lowest percentage $(37.71 \%)$ was attained at $\mathrm{F} 3$. The recorded emergence percentages of developed resistance in adult moths were $70.33,55.06,41.18$ and $43.65 \%$ in F1, F6, F8 and F10, respectively compared with $90.38 \%$ in control. The reduction percentage in adult emergence was ranged between 8.9 and $58.1 \%$ during the selected generations.

The prolongation in both larval and pupal durations and the reduction percentages in pupation adult emergence of $S$. littoralis due to treatment with 
nomolt action against the pest were studied by several authors on the same insect species treated with other chitin synthesis inhibitors. In this field of study Sabry (2007) showed that a resistance strain of Pectinophora gossypiella to both atabron and cascade having a distinct latent effects on the larval and pupal durations. The reduced number of larvae entering pupation or moth emergence could be a result of accumulation of toxic material in the insect's body.

Menka and Gupta (2013) found that the effect of novaluron on prolongation of Euproctis icilia the life span was less than buprofezin which exhibited greater increase in the larval longevity.

Table 2. Latent effect of nomolt on the larval and pupal durations, pupation and adult emergence percentages in Spodoptera littoralis pretreated as $4^{\text {th }}$ instar larvae during developed resistance in the pest to the insecticidal action

\begin{tabular}{|c|c|c|c|c|}
\hline $\begin{array}{c}\text { No. } \\
\text { Generations }\end{array}$ & $\begin{array}{c}\text { Mean larval } \\
\text { duration } \\
\text { (days } \pm \text { S.E.) }\end{array}$ & $\begin{array}{l}\text { Mean pupal } \\
\text { duration } \\
\text { (days } \pm \\
\text { S.E.) }\end{array}$ & $\begin{array}{c}\text { Pupation } \\
(\%) \\
+\% \text { reduction }\end{array}$ & $\begin{array}{c}\text { Adult } \\
\text { emergence } \\
(\%) \\
+\% \text { reduction }\end{array}$ \\
\hline Control & $10.0^{\mathrm{e}} \pm 0.32$ & $10.5^{\mathrm{b}} \pm 0.3$ & 97.0 & 90.08 \\
\hline $\begin{array}{c}\text { Treated } \\
\text { parent (F0) }\end{array}$ & $\begin{array}{c}11.25^{\mathrm{d}} \pm 0.25 \\
(12.5)\end{array}$ & $\begin{array}{c}10.9^{b} \pm 0.3 \\
(3.81) \\
\end{array}$ & $\begin{array}{c}56.7 \\
(42.3)\end{array}$ & $\begin{array}{r}82.09 \\
(8.9) \\
\end{array}$ \\
\hline $\mathrm{F} 1$ & $\begin{array}{c}12.01^{\mathrm{cd}} \pm 0.29 \\
(20.1)\end{array}$ & $\begin{array}{c}12.5^{\mathrm{a}} \pm 0.29 \\
(19.05)\end{array}$ & $\begin{array}{r}55.0 \\
(43.3) \\
\end{array}$ & $\begin{array}{l}70.33 \\
(21.9) \\
\end{array}$ \\
\hline F3 & $\begin{array}{c}11.75^{\mathrm{d}} \pm 0.25 \\
(17.5)\end{array}$ & $\begin{array}{c}11.5^{\mathrm{ab}} \pm 0.61 \\
(9.52)\end{array}$ & $\begin{array}{l}43.85 \\
(54.8)\end{array}$ & $\begin{array}{c}37.71 \\
(58.1)\end{array}$ \\
\hline F6 & $\begin{array}{c}13.5^{\mathrm{b}} \pm 0.29 \\
(35.0)\end{array}$ & $\begin{array}{c}11.0^{\mathrm{b}} \pm 0.41 \\
(4.76)\end{array}$ & $\begin{array}{l}27.35 \\
(71.8) \\
\end{array}$ & $\begin{array}{l}55.06 \\
(38.9) \\
\end{array}$ \\
\hline F8 & $\begin{array}{c}14.5^{\mathrm{a}} \pm 0.62 \\
(45.0) \\
\end{array}$ & $\begin{array}{c}10.5^{b} \pm 0.29 \\
(0.0)\end{array}$ & $\begin{array}{l}24.66 \\
(74.6) \\
\end{array}$ & $\begin{array}{l}41.18 \\
(54.3) \\
\end{array}$ \\
\hline F10 & $\begin{array}{c}12.8^{\mathrm{bc}} \pm 0.41 \\
(20.8)\end{array}$ & $\begin{array}{c}12.7^{\mathrm{a}} \pm 0.29 \\
(20.95)\end{array}$ & $\begin{array}{l}33.56 \\
(65.4) \\
\end{array}$ & $\begin{array}{l}43.65 \\
(51.5) \\
\end{array}$ \\
\hline F. Value & $23.81^{* * *}$ & $5.2333^{* *}$ & & \\
\hline L.S.D. & 0.9047 & 1.2024 & & \\
\hline
\end{tabular}

Numbers between brackets presented \% prolongation in case of larval and pupal durations and \% reduction in case of pupation and adult emergence percentages. Numbers of the same letters have no significant difference

\section{Biochemical studies:}

Results illustrated in Tables 3 showed the changes in alpha and beta non-specific esterases, chitinase and protease activities, in six days after treatment of the $4^{\text {th }}$ instar larvae of $S$. littoralis during selection with nomolt. The data expressed as percentages either increase or decrease in the enzymatic activities.

During selection with nomolt, the activities of a-esterase showed significant difference in the selected generations comparing with control. At the beginning, in the 
treated parent (F0), the activity of a esterase were increased significantly from 529.97 $\mu \mathrm{g}$ a-naphthyl acetate/ $\mathrm{min} / \mathrm{mg}$ in the normal larvae to 632.93 then this activity increased to reach 983.45 and $992.58 \mu \mathrm{g}$ a-naphthyl acetate/ $\mathrm{min} / \mathrm{mg}$ in F3 and F6 generations, respectively. Again the activities were decreased to reach $509.60 \mu \mathrm{g}$ anaphthyl acetate/ min/ $\mathrm{mg}$ in F10 generation more than the control.

Assummarized in Table (3), $\beta$-esterase activity were significantly decreased in the treated parent (247.31 $\mathrm{mg} \beta$-naphthyl acetate/ $\mathrm{min} / \mathrm{mg}$ ) compared with the control which recorded $507.21 \mathrm{\mu g} \beta$-naphthyl acetate/ $\mathrm{min} / \mathrm{mg}$ then this activity was significantly increased to be $612.79 \mu \mathrm{g} \beta$-naphthyl acetate/ min/ mg in F3. In F6 and F10, the level of activity decreased to reach 479.21 and $497.89 \mu \mathrm{g} \beta$-naphthyl acetate/ $\mathrm{min} / \mathrm{mg}$, respectively as compared with the control.

It could be concluded that nomolt caused a significant decrease or increase alternation in the activities of $a$ - and $\beta$-esterases, in the treated larval instar. The changes in esterases activities during the larval life was coincide with the titer of $\mathrm{JH}$ (Riddiford and truman, 1978).

The variation in the measused esterases activity by nomolt treatment indicated that, these enzymes may play an important role in resistance in the cotton leafworm $S$. littoralis to chitin synthesis inhibitors toxicity. In this respect, Farag (2005) suggested that the most of tested $S$. littoralis field strains tissue showed a high activity of esterases than the laboratory strain with exception in haemolymph. It was concluded that the increase in esterase activities could play an important role in cotton leafworm resistance development to nomolt action. Bakr et al. (2010) evaluated the effect of sublethal doses $\mathrm{LC}_{25}, \mathrm{LC}_{50}$ and $\mathrm{LC}_{90}$ of Cascade (Flufenoxuron) on enzymatic activities against $2^{\text {nd }}$ and $4^{\text {th }}$ larval instars of $S$. littoralis. The treated larvae showed a significant decrease in enzyme activities of acid phosphatase as well as a, $\beta$-esterases non- specific esterases, at different intervals times post treatments.

The activity of chitinase enzyme of untreated S. littoralis larvae was $20.94 \mu \mathrm{g} \mathrm{N}$ acetylglucosamine (NAGA)/min/g. The results showed high significant increase in the treated larvae with nomolt in F3, F6 and F10 which generation being 33.35, 28.70 and $28.77 \mu \mathrm{g} \mathrm{NAGA} / \mathrm{min} / \mathrm{g}$, respectively. On the other hand, significant decrease was recorded in the treated parent (F0) which recorded $15.88 \mu \mathrm{g} \mathrm{NAGA} / \mathrm{min} / \mathrm{g}$ comparing with that in the untreated larvae.

The previous results are going in line with those published by Al-Shannaf et al. (2012). They declared that atabron and admeral gave highly significant increase in the activity of chitinase enzyme. On contrast, Sabry (2007) revealed that, atabron, cascade and Xentari reduced the chitinase activity of $P$. gossypiella resistant strain to especially in cascade -resistant field strain.

As shown in Table 3, the activity of protease enzyme in the treated parent was significantly decreased from $293.60 \mu \mathrm{g}$ casein/min/ $\mathrm{mg}$ in the control to 156.25 
$\mu \mathrm{g}$ casein/min/ $\mathrm{mg}$ in the treated parent then this activity was increased to reach $280.21 \mu \mathrm{g}$ casein/min/ mg in F3. This activity significantly increased to $422.57 \mu \mathrm{g}$ casein/min/ $\mathrm{mg}$ in F6 and then it was decreased to $305.02 \mu \mathrm{g}$ casein/min/ $\mathrm{mg}$ in the generation.

It is interest to note that protease enzyme could play an important role in the resistance development throughout protein digestion by releasing amino acids from the peptides. The results are accordance with those published Sabry (2007). They stated found that the activity of protease was increased in Xentari resistant strain and chitin synthesis inhibitors resistant strain in the pink bollworm $P$. gossypiella.

Table 3. enzymes activities of $S$. littoralis larvae after six days of treatment as $4^{\text {th }}$ instar larvae with at $\mathrm{LC}_{50}$ values of nomolt.

\begin{tabular}{|c|c|c|c|c|}
\hline $\begin{array}{c}\text { Treated } \\
\text { Generations } \\
\text { No. }\end{array}$ & $\begin{array}{c}\text { a-Esterase } \\
\mu \mathrm{g} \text { a- naphthyl } \\
\text { acetate/ } \mathrm{min} / \mathrm{mg}\end{array}$ & $\begin{array}{c}\beta \text {-Esterase } \\
\mu g \text {-naphthyl } \\
\text { acetate/ min/ mg }\end{array}$ & $\begin{array}{c}\text { Chitinase } \\
\mu \mathrm{g} \mathrm{NAGA} / \mathrm{min} / \mathrm{g}\end{array}$ & $\begin{array}{c}\text { Protease } \\
\mu \mathrm{g} \text { casein } / \mathrm{min} / \mathrm{mg}\end{array}$ \\
\hline Control & $529.97^{c} \pm 18.47$ & $507.21^{\mathrm{b}} \pm 7.56$ & $20.94^{c} \pm 0.556$ & $293.60^{b} \pm 8.987$ \\
\hline $\begin{array}{c}\text { Treated } \\
\text { parent(F0) }\end{array}$ & $632.93^{b} \pm 17.01$ & $247.31^{d} \pm 3.30$ & $15.88^{d} \pm 0.441$ & $156.25^{\complement} \pm 4.701$ \\
\hline F3 & $983.45^{\mathrm{a}} \pm 36.91$ & $612.79^{a} \pm 9.65$ & $33.35^{\mathrm{a}} \pm 0.978$ & $280.21^{\mathrm{b}} \pm 8.621$ \\
\hline F6 & $992.58^{\mathrm{a}} \pm 35.29$ & $479.21^{\mathrm{c}} \pm 8.13$ & $28.70^{b} \pm 0.825$ & $422.57^{\mathrm{a}} \pm 13.098$ \\
\hline F10 & $509.60^{c} \pm 17.28$ & $497.89^{\mathrm{bc}} \pm 8.45$ & $28.77^{b} \pm 0.824$ & $305.02^{b} \pm 9.306$ \\
\hline F. Value & $81.906^{* * *}$ & $302.933^{* * *}$ & $87.0346^{* * *}$ & $102.989^{* * *}$ \\
\hline L.S.D. & 83.7076 & 24.3268 & 2.3637 & 29.3688 \\
\hline
\end{tabular}

Numbers of the same letters have no significant difference. NAGA: N-acetylglucosamine

\section{REFERENCES}

1. Abbott, W. S. 1925. A method for computing the effectiveness of an insecticide. J. Econ. Entomol., 18: 265- 267.

2. Al-Shannaf, H.M., H. M. Mead and H. S. Al-Kazafy. 2012. Toxic and biochemical effects of some bioinsecticides and IGRs on American Bollworm, Helicoverpa armigera (Hub.) (Lepidoptera: Noctuidae) in Cotton fields. J. Biofert. Biopest., 3:(2):1-6.

3. Bakr, R.F.A., N. El-Bakry, M. Abd Elaziz, M. Awad and H. Abd El-Halim. 2010. Effect of Chitin synthesis inhibitors (flufenoxuron) on some biological and 
biochemical aspects of the cotton leaf worm, Spodoptera littoralis (Bosid.)(Lepidoptera: Noctuidae). Egypt. Acad. J. Biol. Sci., 2 (2): 43- 56.

4. Brattsten, L.B. 1989. Insecticide resistance and management.Pest. Sci., 26 (1): 329-332.

5. Duncan, D. B. 1955. Multiple range and multiple F-test. Boimetrics, 11 (1): 124.

6. El-Defrawi, M. E., A. Toppozada, N. Mansour and M. Zeid. 1964. Toxicological studies on Egyptian cotton leafworm Prodenia litura (F.). I: Suceptiblity of different larval instars to insecticides.J. Econ. Entomol., 57 (4): 591- 593.

7. Farag, M. A. 2005. Biochemical studies on insecticides resistance mechanisms of field and laboratory cotton leafworm strains. Ph.D. Thesis, Fac. Agric., Cairo Univ., Egypt.

8. Finney, D. J. 1971. Probit Analysis: a Statistical Treatment of the Sigmoid Response Curve. P. 33. Cambridge Univ. Press, London.

9. Ghoneim, Y. F., M. Singab, H. M. Abou-Yousef and N. S. Abd-El-Hai. 2012. Efficacy of certain insecticides and their mixtures with the tested IGRs against a field strain of the cotton leaf worm, Spodoptera littoralis (Boisd.) under laboratory conditions. Aust. J. Basic \& App. Sci. 6(6):300-304.

10. Ishaaya, I. and J. E. Casida. 1974. Dietary TH 6040 alters composition and enzyme activity of housefly larval cuticle. Pestic. Biochem. Physiol., 4: 484- 490.

11. Ishaaya, I., I. Moore and D. Joseph. 1971. Protease and amylase activity in larvae on the Egyptian cotton worm, Spodoptera littoralis. J. Insect Physiol. 17: 45-53.

12. Litchfield, J. T. and F. Wilcoxon. 1949. Asimplified method of evaluation doseeffect experiments. J. Pharmacol . exp. Ther., 96-99.

13. Menka, G. and A. K.Gupta. 2013. Experimental analysis of chitin synthesis inhibitors against the larvae of Euprotis icilia Stoll: longevity and weight loss. J. Exp. Zool. India. 16(2):583-590.

14. Riddiford, L. M. and J. W. Truman. 1978. Biochemistry of insect hormones and insect growth regulatores. Biochemistry of insects. (M. Rockstien, Ed.). p. 307.

15. Sabry, A. H. 2007. Resistance of the Pink bollworm, Pectinophora gossypiella(Saunders) to some nonconventional pest control agents.Ph.D. Thesis, Fac. Agric., Zagazig Univ., Egypt.

16. Scott, J. G. 1998. Toxicity of spinosad to susceptible and resistant strain of house flies. Muscadomestica. Pest. Sci. 54: 131-133.

17. Van Asperen, K. 1962. A study of housefly esterase by means of sensitive colourimetric method.J. Insect Physiol., 8: 401- 416. 
تطور الحساسية فى يرقات دودة ورق القطن المعاملة بمركب النومولت وعلاقتها بالتغير ات البيولوجية والكيميائية فى جسم الحشرة

الثيماء نجيب إبراهيم- عزة كمال إمام²- قدري وشاحى محمود2-- عزيزة السيد عبد العال1

$$
\begin{aligned}
& \text { 1. معهُ بحوث وقاية النباتات - مركز البحوث الزراعية - الدقي- جيزة - مصر. }
\end{aligned}
$$

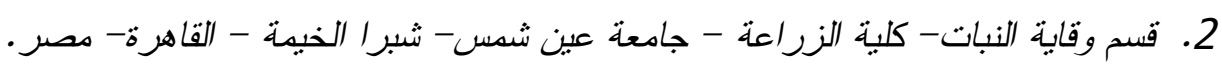

أجري هذا البحث لدراسة حساسية برقات العمر الرابع لحشرة دودة ورق القطن (رتبة

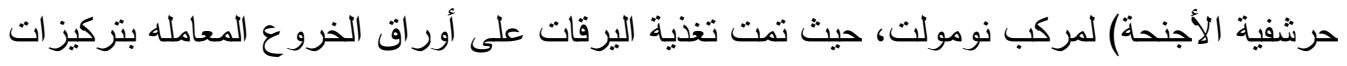

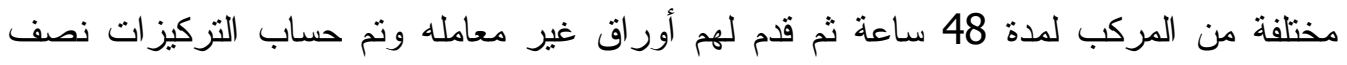

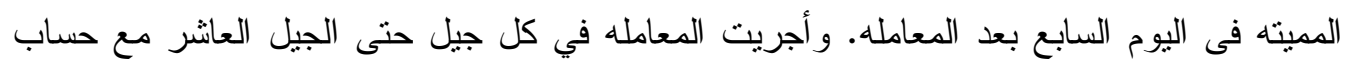

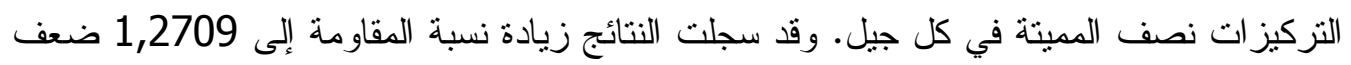
بعد الجيل الثالث ثم إلى الى 1,2894 و 2,3034 و

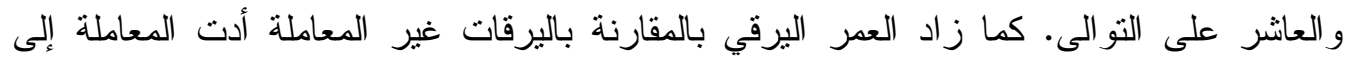

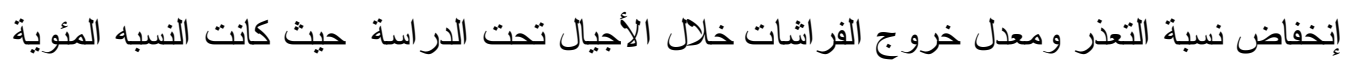
للتعذر 56,7، 55,0، 43,85، 27,35، 24,66 و 33, 33,56 وكان النسب المئوية لخروج الفر اشثات 82,09، 70,33، 37,71، 55,05، 41,18 و 43,65 لجيل الآباء، الجيل الأول، الجيل الثالث،

$$
\text { الجيل الثامن و الجيل العاشر على التو الى لى الت. }
$$

أظهرت النتائج ارتفاعا فى نشاط الإنزيمات المختبرة بعد 6 أيام من المعاملة ليرقات العمر

الر ابع إرتفاعا و إنخفاضا خلال الأجيال العشره المختبره. 